\title{
Pharmacotherapeutic Options for Ophthalmic Conjunctivitis
}

\author{
van Eyk AD, PhD, BSc(Hons)Pharmacol, BCom, Senior Lecturer \\ Division of Pharmacology, Department of Pharmacy and Pharmacology, School of Therapeutic Sciences \\ Faculty of Health Sciences, University of the Witwatersrand \\ Corresponding author, email: Armorel.vanEyk@wits.ac.za
}

\begin{abstract}
Conjunctivitis is a common eye condition involving inflammation and in some instances infection of the conjunctiva. In the majority of cases it is caused by adenoviruses and, to a lesser extent, bacteria. Conjunctivitis can also occur secondary to Chlamydial and Gonococcal infections and new-born infants can acquire it during the birthing process from infected mothers. Herpes simplex and Herpes zoster are the infective organisms also responsible for conjunctivitis while seasonal pollens are usually the cause for allergic conjunctivitis. Common symptoms and signs are redness, tearing, oedema of the eyelids, sensation of a foreign body and it may be accompanied by itching. Most often a purulent discharge and adherence of eyelids at awakening are indicators of a bacterial infection. Most of the uncomplicated acute cases are self-limiting. There is however a challenge in distinguishing between the various types of conjunctivitis due to the similarity in the symptoms and due to a lack of tests and prediction algorithms, thus antibiotic therapy is often incorrectly initiated. Treatment of acute uncomplicated conjunctivitis caused by adenoviruses and bacteria is mostly symptomatic. Topical eye drops and ointments are preferred to oral agents in the treatment of more severe bacterial and allergic conjunctivitis while oral agents are used in the treatment of conjunctivitis caused by Herpes simplex, Herpes zoster, Chlamydia trachomatis and Neisseria gonorrhoeae.
\end{abstract}

Keywords: Infective conjunctivitis; Allergic conjunctivitis, Viral conjunctivitis; Bacterial conjunctivitis, Pink eye

\section{Conjunctivitis}

Conjunctivitis is an inflammatory eye condition that involves the conjunctiva, a highly vascularised, thin and translucent membrane that covers the anterior portion of the sclera and the inside of the eyelids. ${ }^{1-7}$ It presents as a red or pink eye due to the dilation of the blood vessels that leads to hyperaemia and oedema of the conjunctiva. This process typically is associated with some form of discharge. ${ }^{1-6}$ The most common causes of conjunctivitis are viruses, bacteria, allergens and irritants. ${ }^{1-10}$ Infectious conjunctivitis is most often caused by viruses as opposed to bacteria. Furthermore, conjunctivitis can be classified into acute, hyperacute and chronic as well as primary and secondary to a systemic disease, e.g. chlamydia or gonorrhoea. 1,2,4,11 Patients are usually initially seen by their primary health care providers and not ophthalmologists or optometrists, with a typical diagnosis of acute conjunctivitis. In the majority of cases, conjunctivitis will be self-limiting. Because of the difficulty in distinguishing between bacterial and viral conjunctivitis, in the majority of the cases, topical antibiotic therapy is initiated as there is a lack of tests or

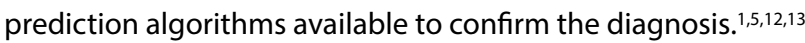

\section{Infectious conjunctivitis}

\section{Viral conjunctivitis (adenoviruses)}

Adenoviruses are most often the cause of acute infectious conjunctivitis. $12,4,6,8,9,11$ Unfortunately, due to the similarity of presenting clinical symptoms, it is usually misdiagnosed as caused by bacteria. ${ }^{4,10,12}$ Presenting symptoms include a high fever, pharyngitis, bilateral conjunctivitis and swelling of the periauricular lymph nodes (pharyngoconjunctival fever) or in more severe cases as hyperaemia, swelling of the conjunctiva, watery discharge and swollen lymph glands (epidemic keratoconjunctivitis). Swollen lymph glands are more prevalent in viral conjunctivitis and this infection is also highly contagious. Strict sanitation measures and isolation of patients should be advocated, as the incubation period is estimated at 5-12 days and the period of communicability is $10-14$ days. Symptoms usually resolve over 1-3 weeks. This condition is usually selflimiting. ${ }^{1-4,6-9,11}$ Topical antibiotics are sometimes mistakenly prescribed for this viral infection due to incorrect diagnosis of the causative agent. This not only leads to an increased risk of toxicity and allergies, but also delays the diagnosis of other ocular diseases and increases the risk of resistance developing. ${ }^{1,4,5,12,13}$ Unfortunately, antiviral medication is not useful and because there is no effective treatment for this condition, the use of topical antihistamines, cold compresses and artificial tears might help in the alleviating of symptoms (Table I). ${ }^{1-4,6-9,11,14,15}$ If the condition does not resolve within 7-10 days, the patient should be referred to an ophthalmologist. ${ }^{1,15}$

\section{Viral conjunctivitis (Herpes)}

Conjunctivitis caused by the Herpes simplex virus is not as common and presents usually only in one eye with accompanying thin and watery discharge as well as vesicular eyelid lesions. Patient should be referred to a specialist ophthalmologist. Treatment is preferentially topical and oral aciclovir or alternatively oral valaciclovir (Table I). Topical aciclovir is occasionally associated 
with transient stinging after administration while the oral antiviral agents are usually well-tolerated. $1,2,4,7,11,15-17$

Conjunctivitis caused by the Herpes zoster virus that is responsible for shingles, usually involves the eyelids or conjunctiva and may result in uveitis and corneal complications. Patients should be referred to an ophthalmologist with any eye involvement. Treatment usually consists of oral aciclovir, famciclovir or valaciclovir (Table I). ${ }^{1,2,4,7,11,15-17}$

\section{Bacterial conjunctivitis}

The second most common acute infectious conjunctivitis is bacterial conjunctivitis. ${ }^{1,10,11}$ It is also the most common cause of conjunctivitis in children. ${ }^{11,18}$ Transfer can occur easily from an infected individual by means of direct contact or infection can occur via conjunctival flora over-proliferation. Certain conditions that may also predispose an individual to bacterial conjunctivitis include trauma, compromised immune system, dry eyes, epithelial barrier disruption and adnexal ocular structure abnormalities.111,19 Presenting symptoms include redness, lack of itching, photophobia and a sensation of a foreign body in the eye. Discharge is usually purulent, yellowish in colour causing bilateral eyelid crusting that results in eyelids sticking together upon waking. The incubation period is estimated at 1-7 days and the period of communicability is $2-7$ days. ${ }^{1-5,11,13,14,18-20}$ The causative agents are either Staphylococcus aureus, Staphylococcus epidermis, Streptococcus pneumoniae or Haemophilus influenzae in adults and Haemophilus influenza, Streptococcus pneumoniae or Moraxella catarrhalis in children. $1,2,4,6,8,9,11,18,20,21$ This eye infection is usually self-limiting within 1-2 weeks, however topical antibiotics are usually prescribed if symptoms do not improve on their own with supportive care within 2 days. Topical antibiotics render the patient less infectious to others and decrease the duration of the disease. ${ }^{1,2,4,6-11,1315,18-23}$ The first line treatment for acute bacterial conjunctivitis in South Africa is chloramphenicol eye drops or ointment (Table I). 3,15,17 Treatment should not exceed 5 days, to limit adverse effects and resistance developing. With frequent application, serious overuse and long-term use, optic neuropathies, blood dyscrasias and aplastic anaemia have been reported..$^{15-17}$ In the event of inadequate response to chloramphenicol or confirmed resistant organisms, topical fusidic acid eye drops, aminoglycoside eye drops or ointment (framycetin, tobramycin, neomycin), fluoroquinolone eye drops (ciprofloxacin and gatifloxacin) or bacitracin/polymyxin B eye ointment can be prescribed (Table I). 1,2,4,8,9,11,16-23 Fusidic acid is effective against staphylococci, however due to an increased risk of resistance it is not a first line agent. Adverse effects are usually transient stinging and hypersensitivity. ${ }^{15,16}$ Aminoglycoside treatment should be reserved only for severe sight-threatening infections caused by Gram negative bacteria, as they have incomplete Gram positive bacterial coverage. Transient burning and stinging and an increased risk of hypersensitivity and Pseudomonas resistance have been reported.5,15-17,20 Fluoroquinolones have a broad spectrum of activity, however they are not first line agents due to the possibility of resistance developing. ${ }^{5,15-17,20} \mathrm{Adverse}$ effects are common and include burning, eye discomfort, conjunctival hyperaemia, crusting, and a bad taste. In rare cases allergic reactions, lid oedema, keratitis, light sensitivity, tearing and visual disturbances were noted. ${ }^{15}$ Bacitracin/Polymyxin B eye ointment is only used for superficial eye infections and only in combination formulations. Stinging and burning have been reported after administration. ${ }^{5,15,16}$

The use of topical steroids for the treatment of bacterial conjunctivitis should be avoided as there is an increased risk of potentiating the infection and prolonging the length of the disease. 1,5,16,17,12,15,22 Where the conjunctivitis lasts for more than 4 weeks it can be considered a chronic infection and patients should be referred to an ophthalmologist. The causative agents in this instance are usually Staphylococcus aureus, Moraxella lacunata and enteric bacteria. In the event of conjunctivitis caused in patients wearing contact lenses, the contact lenses should be removed. Patients should be treated with topical antibiotics effective against Gram negative organisms e.g. fluoroquinolones as mentioned above. ${ }^{1,19}$

\section{Chlamydial conjunctivitis}

\section{Adult inclusion conjunctivitis}

Conjunctivitis that occurs in adults that are sexually active is caused by Chlamydia trachomatis and usually presents unilaterally accompanied in many instances by a concurrent genital infection. It is associated with a purulent or mucopurulent discharge, foreign body sensation, hyperaemia, pre-auricular lymphadenopathy and lymphoid follicle formation. Corneal involvement may occur after a 2-week period of infection and otitis media is a complication. The incubation period is approximately 5-19 days. ${ }^{1,2,4,7,10,11,23-25}$ Treatment options include either oral azithromycin or oral doxycycline (Table I).2, ${ }^{2,15}$ It is important to treat the genital tract disease as well. Sexual partners also need to be treated and a gonorrhoea co-infection needs to be investigated. $1,11,13,15,23-26$

\section{Neonatal inclusion conjunctivitis}

Transmission occurs during birth when the mother is infected with Chlamydia trachomatis and the condition is left untreated. Presenting symptoms in the infant include swollen eyelids, hyperaemia and a purulent discharge. The period of incubation is 1-3 weeks and can persist for 3-12 months if left untreated. There is also an increased risk of pneumonitis and otitis media in these infants. It is strongly recommended that cultures be taken and treatment be based on clinical findings. The infant should be treated systemically with oral erythromycin after cleaning of the eyes immediately after birth (Table I). 1,2,4,7,15,22,23,25

\section{Trachoma}

Trachoma predominantly effects children and occurs mostly in developing countries with low socioeconomic status and poor hygiene. ${ }^{1,7,25}$ It is caused by Chlamydia trachomatis (subtypes A-C) and can result in blindness if left untreated. 1,24,25 Presenting symptoms include mucopurulent discharge, discomfort, redness and swollen eyelids. At least two of the following signs are indicators of trachoma: follicles in the upper tarsal conjunctiva, 


\begin{tabular}{|c|c|c|c|}
\hline Category & $\begin{array}{l}\text { Causative } \\
\text { organism }\end{array}$ & First line treatment & Alternative treatment \\
\hline Acute viral conjunctivitis & Adenoviruses & $\begin{array}{l}\text { Usually self-limiting } \\
\text { - Cold compress } \\
\text { - Artificial tears } \\
\text { - Topical antihistamines }\end{array}$ & \\
\hline Herpes conjunctivitis & Herpes simplex & $\begin{array}{l}\text { Topical acyclovir eye drops in the lower } \\
\text { conjunctival sac ( } 1 \text { drop } 5 x \text { daily at } 4 \text { hour } \\
\text { intervals for } 14 \text { days or till } 3 \text { days after healing, } \\
\text { whichever is shorter) } \\
\text { - Oral aciclovir ( } 400 \text { mg, } 5 x \text { daily for } 7-10 \text { days) } \\
\text { (dose adjustment in children) }\end{array}$ & $\begin{array}{l}\text { - Oral valaciclovir } \\
\text { (500 mg, } 3 x \text { daily for } 7-10 \text { days) } \\
\text { - Oral famciclovir ( } 250 \mathrm{mg}, 3 x \text { daily for } 7-10 \text { days) } \\
\text { - (dose adjustment in children) }\end{array}$ \\
\hline Herpes conjunctivitis & Herpes zoster & $\begin{array}{l}\text { Oral aciclovir ( } 800 \mathrm{mg}, 5 x \text { daily ( } 4 \text { hourly while } \\
\text { awake)) for } 7-10 \text { days } \\
\text { (dose adjustment in children) }\end{array}$ & $\begin{array}{l}\text { Oral famciclovir ( } 500 \mathrm{mg}, 3 x \text { daily for } 7-10 \text { days) } \\
\text { OR } \\
\text { - Oral valaciclovir ( } 1000 \mathrm{mg}, 3 x \text { daily for } 7-10 \text { days) } \\
\text { (dose adjustment in children) }\end{array}$ \\
\hline $\begin{array}{l}\text { Acute bacterial } \\
\text { conjunctivitis }\end{array}$ & $\begin{array}{l}\text { S. aureus, } \\
\text { S. epidermis, } \\
\text { S. pneumoniae } \\
\text { H. influenza } \\
\text { M. catarrhalis }\end{array}$ & $\begin{array}{l}\text { Usually self-limiting } \\
\text { - Chloramphenicol eye drops }(0.5 \%, 1 \text { drop in } \\
\text { the lower conjunctival sac, very } 2 \text { hours for } \\
\text { the first } 2 \text { days, then every } 4 \text { hours for the } \\
\text { next } 3 \text { days) } \\
\text { Maximum } 5 \text { day treatment } \\
\text { OR } \\
\text { - Chloramphenicol ointment ( } 1 \%, 1 \mathrm{~cm} \text { strip in } \\
\text { the lower conjunctival sac, every } 4 \text { hours or } \\
\text { alternatively before bedtime if drops are also } \\
\text { used during the day) } \\
\text { Maximum } 5 \text { day treatment }\end{array}$ & $\begin{array}{l}\text { No response or resistance suspected } \\
\text { - Fusidic acid eye drops ( } 1 \text { drop } 2 \text { x daily continue } \\
\text { until } 2 \text { days after resolution) } \\
\text { OR } \\
\text { Aminoglycosides: } \\
\text { - Framycetin, tobramycin or neomycin ( } 1-2 \text { drops } \\
\text { every } 4 \text { hours or } 1 \mathrm{~cm} \text { ointment strip in the lower } \\
\text { conjunctival sac, } 2-3 x \text { daily for } 7 \text { days) } \\
\text { OR } \\
\text { Fluoroquinolones: } \\
\text { - Ciprofloxacin or gatifloxacin eye drops ( } 1 \text { drop } \\
\text { every } 2 \text { hours for } 2 \text { days followed by } 1 \text { drop every } \\
4 \text { hours for } 5 \text { days while awake) or moxifloxacin } \\
\text { ( } 1 \text { drop } 3 x \text { daily for } 4 \text { days) or ofloxacin ( } 1 \text { drop } \\
\text { every } 2-4 \text { hours for } 2 \text { days followed by } 1 \text { drop } \\
4 x \text { daily for a maximum of } 10 \text { days) } \\
\text { OR } \\
\text { Bacitracin/polymyxin B ointment ( } 1 \mathrm{~cm} \text { strip in } \\
\text { the lower conjunctival sac every } 3-4 \text { hours for } \\
7 \text { to } 10 \text { days) }\end{array}$ \\
\hline $\begin{array}{l}\text { Chlamydial inclusion } \\
\text { conjunctivitis }\end{array}$ & C. trachomatis & $\begin{array}{l}\text { Adults: } \\
\text { - Oral azithromycin (single } 1 \mathrm{~g} \text { oral dose) } \\
\text { Neonatal: } \\
\text { - Clean both eyes immediately after birth } \\
\text { Prophylaxis: } \\
\text { - Chloramphenicol eye ointment ( } 1 \% \text { ) or } \\
\text { povidone-iodine aqueous solution }(2.5 \%) \\
\text { AND } \\
\text { - Oral erythromycin ( } 50 \mathrm{mg} / \mathrm{kg} / \text { day in } \\
4 \text { divided doses for a period of } 14 \text { days) } \\
\text { OR } \\
\text { - Oral azithromycin ( } 20 \mathrm{mg} / \mathrm{kg} \text { single dose or } \\
10 \mathrm{mg} / \mathrm{kg} / \text { day for } 3 \text { days) }\end{array}$ & $\begin{array}{l}\text { Adults: } \\
\text { - Oral doxycycline (100 mg 2x daily for 7-14 days) }\end{array}$ \\
\hline Trachoma & $\begin{array}{l}\text { C. trachomatis } \\
\text { (subtypes A-C) }\end{array}$ & $\begin{array}{l}\text { Adults: } \\
\text { - Oral azithromycin (single } 1 \mathrm{~g} \text { oral dose) } \\
\text { Children: } \\
\text { - Oral azithromycin }(20 \mathrm{mg} / \mathrm{kg} \text { maximum } 1 \mathrm{~g} \text { ) } \\
\text { single dose } \\
\text { Pregnant women, children < } 6 \text { months or } \\
\text { patients allergic to macrolides: } \\
\text { - Topical tetracycline ( } 1 \% \text { eye ointment } 2 \text { x daily } \\
\text { for } 6 \text { weeks) }\end{array}$ & $\begin{array}{l}\text { Adults: } \\
\text { - Oral doxycycline ( } 100 \mathrm{mg} 2 \mathrm{x} \text { daily for } 21-28 \text { days) } \\
\text { OR } \\
\text { - Oral erythromycin ( } 500 \mathrm{mg} 4 \mathrm{x} \text { daily for } \\
21-28 \text { days) }\end{array}$ \\
\hline Gonococcal conjunctivitis & N. gonorrhoeae & $\begin{array}{l}\text { - Irrigate eyes multiple times with sodium } \\
\text { chloride eye drops ( } 0.9 \%) \text { to remove the } \\
\text { discharge } \\
\text { Neonatal: } \\
\text { - Clean both eyes immediately after birth } \\
\text { Prophylaxis: } \\
\text { - Chloramphenicol eye ointment (1\%) or } \\
\text { povidone-iodine aqueous solution ( } 2.5 \%) \\
\text { AND } \\
\text { - IV or IM ceftriaxone ( } 25-50 \mathrm{mg} / \mathrm{kg} \text {, maximum } \\
125 \mathrm{mg} \text { as a single dose) } \\
\text { Adults and adolescents: } \\
\text { - IM ceftriaxone ( } 1 \mathrm{~g} \text { single dose) } \\
\text { AND } \\
\text { - Oral azithromycin ( } 1 \mathrm{~g} \text { single dose) } \\
\text { Chlamydial dual therapy is indicated } \\
\text { Cephalosporin allergic patients: } \\
\text { - Oral azithromycin ( } 2 \mathrm{~g} \text { single dose) }\end{array}$ & $\begin{array}{l}\text { Adults and adolescents: } \\
\text { - IM ceftriaxone ( } 1 \mathrm{~g} \text { single dose) } \\
\text { AND } \\
\text { - Oral doxycycline ( } 100 \mathrm{mg} 2 x \text { daily for } 7-14 \text { days) } \\
\text { Chlamydial dual therapy is indicated }\end{array}$ \\
\hline
\end{tabular}




\begin{tabular}{|c|c|c|c|}
\hline \multicolumn{4}{|c|}{ Allergic conjunctivitis } \\
\hline Acute & $\begin{array}{l}\text { Pollens, animal } \\
\text { dander, mould, } \\
\text { environmental } \\
\text { pollutants etc. }\end{array}$ & $\begin{array}{l}\text { Usually self-limiting } \\
\text { Topical Vasoconstrictor/ antihistamine } \\
\text { combination ( } 1-2 \text { drop up to } 4 x \text { daily for up to } \\
48 \text { hours) } \\
\text { - Naphazoline/antazoline } \\
\text { OR } \\
\text { - Tetryzoline/antazoline }\end{array}$ & $\begin{array}{l}\text { Topical antihistamines with mast cell stabilizing } \\
\text { effects } \\
\text { Emedastine, epinastine, ketotofen, olopatadine } \\
\text { (1 drop } 2 x \text { daily up to } \\
2 \text { weeks) }\end{array}$ \\
\hline Seasonal & & $\begin{array}{l}\text { Topical antihistamines with mast cell stabilizing } \\
\text { effects } \\
\text { - Emedastine, epinastine, ketotofen, } \\
\text { olopatadine } \\
\text { ( } 1 \text { drop } 2 \text { x daily } 2-4 \text { weeks before expected } \\
\text { onset of symptoms) }\end{array}$ & $\begin{array}{l}\text { Topical mast cell stabilisers } \\
\text { - Cromoglicic acid ( } 1 \text { drop } 4 x \text { daily) or lodoxamide } \\
\text { ( } 1-2 \text { drops } 4 x \text { daily up to } 4 \text { weeks) }\end{array}$ \\
\hline Perennial & & $\begin{array}{l}\text { Topical antihistamines with mast cell stabilizing } \\
\text { effects } \\
\text { - Emedastine, epinastine, ketotofen, } \\
\text { olopatadine } \\
\text { ( } 1 \text { drop } 2 x \text { daily) }\end{array}$ & $\begin{array}{l}\text { Topical mast cell stabilisers } \\
\text { - Cromoglicic acid ( } 1 \text { drop } 4 x \text { daily) or lodoxamide } \\
\text { ( } 1-2 \text { drops } 4 x \text { daily) }\end{array}$ \\
\hline
\end{tabular}

limbal follicles/ sequelae and scarring of the conjunctiva, cornea and eyelids accompanied by intense inflammation. 1,3,7,24,25 The WHO (World Health Organization) recommends community-wide treatment if the active incidence of 1-9 year-old children within the community is $>10 \%$. Treatment is either oral azithromycin or topical tetracycline alternatively, oral doxycycline or oral erythromycin (Table I). 1,3,7,15,24,25

\section{Gonococcal conjunctivitis}

This severe form of conjunctivitis is caused by Neisseria gonorrhoeae in new-born infants that acquire it during birth, and sexually active adults and adolescents. It presents as severe swollen eyelids, profuse thick purulent discharge with an accompanying increased risk of perforation or ulceration of the corneas. ${ }^{1-4,7,11,20}$ Eyes should be irrigated to remove the discharge and treated topically. Infants should also be treated systemically with either IV or IM ceftriaxone. Treatment of adults and adolescents consists of IM ceftriaxone and oral azithromycin (Table I). The possibility of a co-infection with Chlamydia trachomatis should be considered and treatment should be accordingly. ${ }^{1-4,7,11,13,15,17,18,20,22,26}$

\section{Non-infectious conjunctivitis}

\section{Allergic conjunctivitis}

The presence of allergens, e.g. pollen and animal dander, may result in an inflammatory response of the conjunctiva. Three types exist, i.e. acute, seasonal and perennial.2,4,27 Presenting symptoms are itching, redness, eyelid oedema and watery discharge. ${ }^{1-5,7-9,11,21}$ Patients should be instructed to avoid the offending allergen and encouraged to irrigate the eyes with saline or artificial tears. Treatment options include topical antihistamines, decongestants and mast cell stabilisers (Table I). 1,3,4,5,7,11,16,27 Topical decongestants should not be used long-term due to the risk of reactive hyperaemia. ${ }^{11,15,16,27}$ Adverse effects of topical agents are usually transient stinging and in some instances CNS effects. ${ }^{15,16}$ The use of non-sedating oral antihistamines may be indicated although topical agents were found to be superior. Topical corticosteroids should be discouraged for mild inflammatory conditions due to complications. ${ }^{1,8,9,11,15,27}$

\section{Chemical-induced conjunctivitis}

Various topical agents instilled into the eyes can induce allergic reactions with symptoms similar to those observed for viral conjunctivitis, e.g. the presence of the preservative benzalkonium chloride in eye drops. Usually symptoms will cease after stopping these offending agents. 1,2,3,7

\section{Conclusion}

Conjunctivitis is one of the most common eye disorders seen by health care providers at the primary level, and the two most common forms of infectious conjunctivitis are non-herpetic viral (adenovirus) and bacterial in nature. Seasonal allergic conjunctivitis is also very common and due mostly to pollens. Most are self-limiting, however in more severe cases, antibiotic therapy is inappropriately initiated due to the similarity of symptoms which leads to an inaccurate diagnosis. Treatment is usually topical eye drops or ointments except in the cases of herpes, chlamydial and gonococcal infections where topical, oral and in some instances IV or IM medications are indicated.

\section{References}

1. Azari AA, Barney NP. Conjunctivitis: A Systematic Review of Diagnosis and Treatment. JAMA. Oct 2013;310(16):1721-9. doi:10.1001/jama.2013.280318

2. Optometric Clinical Practice Guideline: Care of the Patient with Conjunctivitis, American Optometric Association. 2002 [Accessed on 6 Feb 2018]. Available from: https://www.aoa.org/documents/optometrists/CPG-11.pdf

3. National Guideline on Management and Control of Eye Conditions at Primary Level. Dec 2005 [Accessed on 6 Feb 2018]. Available from: https://www. westerncape.gov.za/text/2003/eye2.pdf

4. American Academy of Ophthalmology Cornea/External Disease Panel. Preferred Practice Pattern Guidelines. Conjunctivitis. San Francisco, CA: American Academy of Ophthalmology. 2013 [Accessed on 6 Feb 2018]. Available from: https://www. aao.org/preferred-practice-pattern/conjunctivitis-ppp--2013

5. Melton R, Thomas R, Vollmer P. Clinical Guide to Ophthalmic Drugs [Supplement]. May 2017 [Accessed on 6 Feb 2018]. Review of Optometry. 
Available from: https://www.reviewofoptometry.com/CMSDocuments/2016/5/ dg0516i.pdf

6. Peterson G. Conjunctivitis [Module]. Unit for Medication Outcomes Research and Education, School of Pharmacy, University of Tasmania 2010[Accessed on 6 Feb 2018]. Available from: http://www.auspharmacist.net.au/CE/CE100422_ Conjunctivitis.pdf

7. Senaratne T, Gilbert C. Primary Health Care Conjunctivitis. Community Eye Health. Mar 2005 [Accessed on 6 Feb 2018];18(53):73-5. Available from: https:// www.cehjournal.org/wp-content/uploads/red-eye-the-role-of-primary-care.pdf

8. Pediatric Conjunctivitis - CRNBC. Aug 2016 [Accessed on 6 Feb 2018]. Remote Nursing Certified Practice, Pediatric Decision Support Tool: Eye-Conjunctivitis. Available from: https://www.crnbc.ca/Standards/CertifiedPractice/Documents/ RemotePractice/754PediatricConjunctivitisDST.pdf

9. Adult Conjunctivitis - CRNBC. Aug 2016 [Accessed on 6 Feb 2018]. Remote Nursing Certified Practice, Adult Decision Support Tool: Eye-Conjunctivitis. Available from: https://www.crnbc.ca/Standards/CertifiedPractice/Documents/ RemotePractice/728AdultConjunctivitisDST.pdf

10. Visscher KL, Hutnik CML, Thomas M. Clinical Review: Evidence-based treatment of acute infective conjunctivitis. Breaking the cycle of antibiotic prescribing. Can Fam Physician. Nov 2009;55:1071-5.

11. Segal KL, Lai EC, Starr CE. Management of Acute Conjunctivitis. Curr Ophthalmol Rep. 2014;2:116-23. doi: 10.1007/s40135-014-0046-4

12. Keen M, Thompson M. Treatment of Acute Conjunctivitis in the United States and Evidence of Antibiotic Overuse: Isolated Issue or a Systematic Problem? Ophthalmology. Aug 2017 [Accessed on 6 Feb 2018];124(8):10968. Available from: https://www.sciencedirect.com/science/article/pii/ S0161642017315543?via\%3Dihub

13. Lin T-Y, Peng T-C. Mimicking Picture of Infectious Conjunctivitis [Letter]. Am J Me. Feb 2016;129(2):e51. doi:10.1016/j.amjmed.2015.08.043

14. Narayana S, McGee S. Bedside diagnosis of the 'Red eye': A systematic review. Am J Med. 2015[Accessed on 23 Feb 2018];128(11):1220-4. Available from: http://www.amjmed.com/article/S0002-9343(15)00577-X/pdf doi: 10.1016/j. amjmed.2015.06.026

15. Rossiter D, Blockman M, Barnes K, Chughlay MF, Cohen K, Deloedt E, de Waal R et al (eds). Ophthalmologicals. Sensory Organs. South African Medicines Formulary, 12th ed. 2016;568-87.
16. Booysen DJ. South African Guide to Topical Ophthalmic Drugs. 2nd ed. South Africa: Medspec publishing. 2013 [Accessed on 23 Feb 2018]. Available from: http://www.eyesite.co.za/drug-guide/2013\%20SAOA\%20HR\%20web.pdf

17. Smit D. Anti-infective ophthalmic preparations in general practice, $S$ Afr Fam Pract. 2012 [Accessed on 23 Feb 2018];54(4):302-7. Available from: https://doi. org/10.1080/20786204.2012.10874239 doi: 10.1080/20786204.2012.10874239

18. Epling J. Bacterial conjunctivitis. Br Med J (Clin Res Ed). 2012;2:704-24.

19. Clinical Management Guidelines: Conjunctivitis (bacterial). The College of Optometrists. 2016 [Accessed on 6 Feb 2018]. Available from: https:// www.college-optometrists.org/guidance/clinical-management-guidelines/ conjunctivitis-bacterial-.html

20. Bacterial conjunctivitis Etiology. Mitch Medical Healthcare - Pharmacotherapy Principles. Updated 18 April 2017 [Accessed on 6 Feb 2018]. Available from: https://www.mitchmedical.us/pharmacotherapy-principles/bacterialconjunctivitis-etiology.html

21. Sheikh A, Hurwitz B. Topical antibiotics for acute bacterial conjunctivitis: a systematic review. Br J Gen Pract. Jun 2001;51:473-7.

22. Yeung KK, Weissman BA. Bacterial Conjunctivitis (Pink Eye) Treatment and Management. Medscape. Updated Oct 2017 [Accessed on 6 Feb 2018]. Available from: https://emedicine.medscape.com/article/1191730-treatment

23. Titcomb L, Jamieson C. Ophthalmic Infections: Guidelines for the Management of Microbial Conjunctivitis. Birmingham and Midland Eye Centre, review date Aug 2014 [Accessed on 6 Feb 2018]. Available from: http://bmec.swbh.nhs.uk/ wp-content/uploads/2013/03/SWBH-Microbial-Conjunctivitis-OphthalmicInfections-August-2012.pdf

24. Chen Y-M, Hu F-R, Hou Y-C. Effect of oral azithromycin in the treatment of chlamydial conjunctivitis. Eye 2010 [Accessed on 6 Feb 2018];24:985-9. Available from: https://www.nature.com/articles/eye2009264.pdf

25. Ubani U. Trachoma and Inclusion Conjunctivitis. In: Chaudhry IA, editor. Common Eye Infections. Intech Open Access. May 2013 [Accessed on 6 Feb 2018]. Available from: https://www.intechopen.com/books/common-eyeinfections/trachoma-and-inclusion-conjunctivitis doi:10.5772/45964

26. Van Eyk AD. The treatment of sexually transmitted infections. S Afr Fam Prac. 2016 [Accessed on 23 Feb 2018];58(6):12-22. Available from: https://www.safpj. co.za/index.php/safpj/article/viewFile/4592/5465

27. Vally M, Irhuma MOE. Allergic Conjunctivitis. S Afr Fam Pract. 2017 [Accessed on 23 Feb 2018];59(5):5-10. Available from: http://www.safpj.co.za/index.php/safpj/ article/view/4744/5654 